\title{
EMU AND BROLGA, A KAMILAROI MYTH
}

\author{
Peter Austin and Norman B. Tindale
}

\section{INTRODUCTION ${ }^{1}$}

The Kamilaroi (or Kamilaraay) ${ }^{2}$ are an Aboriginal people who traditionally occupied a large tract of country in north-central New South Wales (Tindale 1974, Austin, Williams and Wurm 1980). The Kamilaroi language was spoken in several dialect forms and is closely related to Yuwaaliyaay (the Euahlayi of Parker 1896, 1978) and Yuwaalaraay to the west (see Austin et al 1980, Williams 1980). It is more distantly linked to Wiradjuri and Ngiyampaa of central New South Wales (Austin et al 1980, Donaldson 1980 - see Map 1).

Information about the Kamilaroi language has been collected sporadically for more than a century, beginning with early recordings in the 1850 s. Highlights of these materials are Ridley (1875) and Mathews (1903). More recently, Tindale collected vocabulary items and kinship terms in 1938 (Tindale 1938); and Wurm worked with the last fluent speaker, Peter Lang, in 1955 (Wurm 1955). Dixon and Austin were able to check vocabulary between 1971 and 1973 (see Dixon (1984:217-8)). A description of the language utilising all available materials is being developed (Austin and Wurm (in preparation)).

To date, the only text materials available for Kamilaroi are Bible translations compiled by Rev. William Ridley during his mission among the people of the Namoi region (Ridley 1856 , 1875 - see also Greenway 1911). No mythological texts have been published. We present here a Kamilaroi traditional story as recorded by Tindale in 1938. The text concerns Emu and Brolga and is part of a widespread Australian tradition.

Peter Austin studied at the Australian National University, completing a thesis on the Diyari language of northern South Australia in 1978 (published by Cambridge University Press in 1981). He has carried out linguistic fieldwork in Northern New South Wales (on Kamilaraay), in northern South Australia (Diyari and Ngamini) and the north-west of Western Australia (Kanyara and Mantharta language groups). His current research focus is the Western Australia languages for which he is preparing dictionaries, grammars and text collections. He is presently senior lecturer and Head of the Division of Linguistics, La Trobe University.

Norman B. Tindale studied linguistics at the University of Adelaide in a special course under Professor J. Fitzherbert, following earlier instruction in orthography under Baldwin Spencer in Melbourne. His data gathering commenced with the Ingura people of Groote Eylandt in the Northern Territory in 1921-22 and has included gatherings of texts within every State of the Commonwealth, including one Tasmanian text. Many of his parallel tribal vocabulary lists are currently being studied.

Tindale wishes to indicate that he is not linked with the devising of the new system of orthography used in this paper. His preference still is Intermational Phonetics for text material and Geo. II for geographical terms.

1 Peter Austin wishes to thank Burt Draper, Hannah Duncan, Ron McIntosh, Leila Orcher and Arthur Pitt for sharing their knowledge of Kamilaroi with him. Thanks are also due to R.M.W. Dixon and S.A. Wurm for access to their unpublished fieldnotes. This paper has benefitted from a number of helpful suggestions from Tamsin Donaldson.

2 The name Kamilaroi is spelled Kamilaraay in the transcription adopted by Austin (see Footnote 4 and Austin and Wurm (in preparation)). 
EMU AND BROLGA

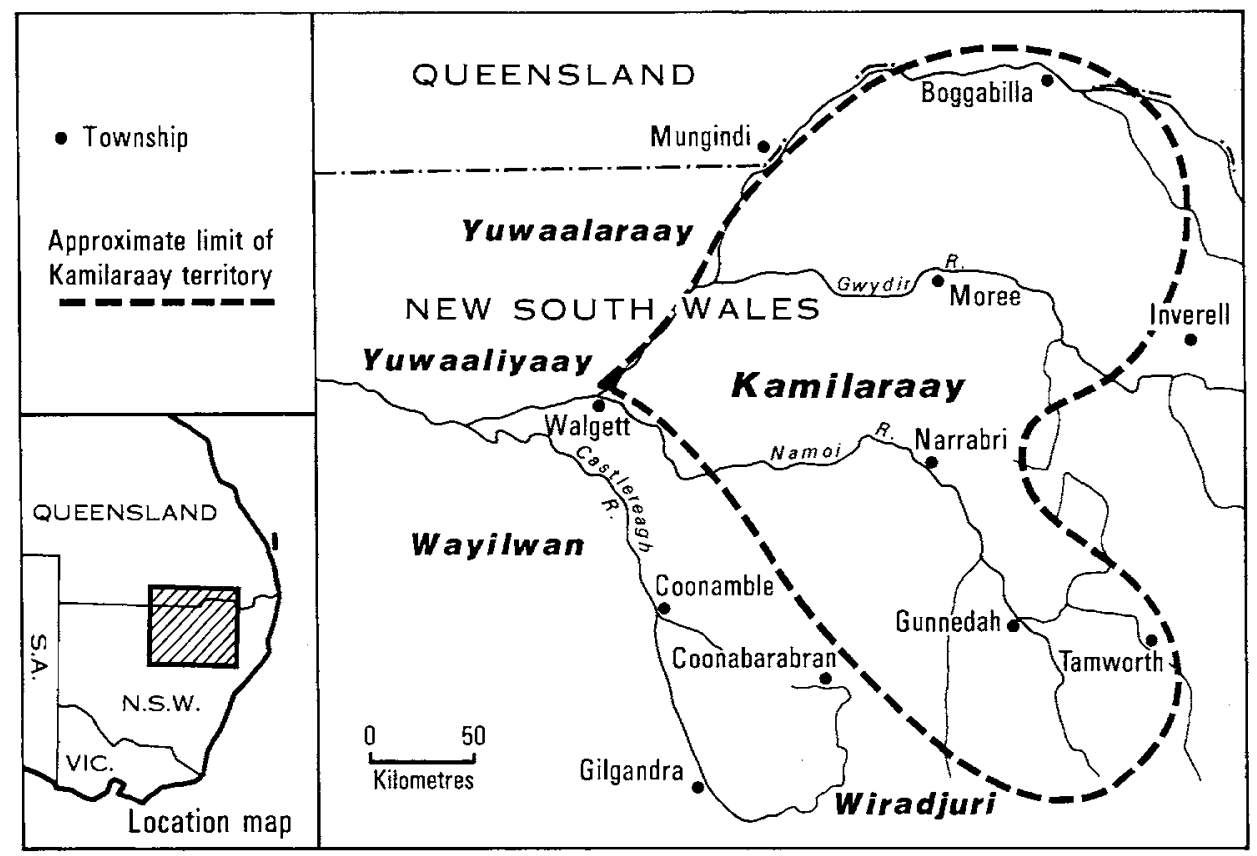

Map 1: Kamilaroi (Kamilaraay) and neighbouring languages.

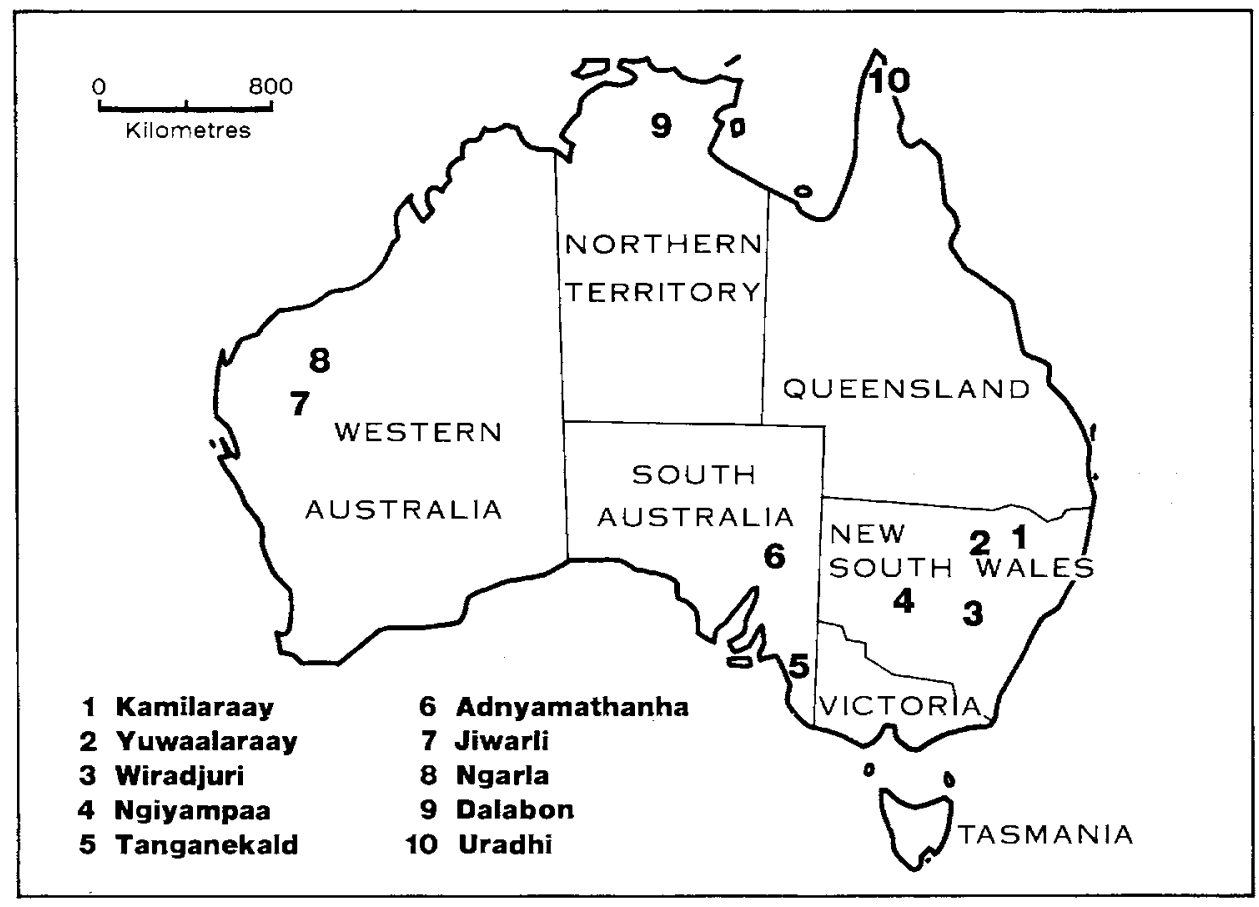

Map 2: Distribution of Emu and Brolga/Bustard myths. 


\section{THE TEXT.}

Tindale carried out anthropological and linguistic research on Kamilaroi during fieldwork conducted as leader of the Harvard-Adelaide Universities Anthropological Expedition of 1938-39. On 18 June 1938 he began work with Harry Doolan ${ }^{3}$ and two other old Aboriginal men on Kamilaroi social organisation and language. In his journal (page 125), he recorded that on Tuesday 21 June he 'obtained the first part of the legend of the Brolga and the emu in text'. The following day, Wednesday 22 June, he notes that he:

obtained the rest of the legend of the Brolga and the emu in text from Harry Doolan, assisted by Stanford. The men were at first at difficulties with their own language because it has not been used by them for some years, except occasionally in conversation. After yesterday they thought out the details carefully and gave me a very useful text in the Kamilaroi of the Namoi River. The story resembles closely the emu and brolga story of the Tanganekald of the Coorong, S.A., in the first half; the sequel is different. I could not get any hints of localization of the legend. It is a camp fire story told by men to their children.

Tindale transcribed the story (journal pp.127-137) in the International Phonetic Alphabet (which had long been standard for writings of the Adelaide School) and obtained from Harry Doolan a word by word translation into English, and for the first nineteen lines plus lines 42 and 43 a running translation of each sentence.

In 1979, when on a visit with Tindale at his home in Palo Alto, California, Austin learned of the text and obtained a copy of it. Because of its uniqueness and historical importance, we decided to publish it in full in the present collection.

In the following, each sentence of the legend is presented in five lines. The first two are the transcription and word by word gloss, exactly as recorded by Tindale, except that the sentences are numbered and capitals at the beginning of sentences are not used (thus obviating the need to print upper case $n$ ). The third line is a respelling of the Kamilaroi words into a phonemic orthography devised by Austin, ${ }^{4}$ plus a division of the words into their likely morphemes, indicated by hyphens. The fourth line presents morpheme-by-morpheme glosses; 5 this glossing is based upon analyses of all the available Kamilaroi material plus William's (1980) grammar of the closely related Yuwaalaraay language. Because no native speaker of Kamilaroi is presently available, the grammatical analysis and glossing must be seen as tentative and in some cases speculative. Where no interpretation could be suggested a ? is employed. The fifth line is the free English translation of each sentence; for the first nineteen sentences (and 42,43) this translation was supplied by Harry Doolan. Austin has prepared a free translation for the remainder (sentences 20 to $41,44-48$ ) based on the grammatical analysis, and this is included in brackets. Harry Doolan provided some additional comments throughout the telling of the story and these are given in angle brackets.

3 A photograph of Harry Doolan may be found in Tindale (1976:18).

4 The spelling is intended as a practical orthography and follows usual Australianist conventions: $t h$ and $n h$ represent lamino-dental stop and nasal respectively; $n g$ is the velar nasal; $n y$ is a lamino-palatal nasal; $r$ is a flap, and $r$ a retroflexed continuant; $R$ indicates that it is unclear whether $r$ or $r$ is intended. Vowel length is indicated by doubling. Where a word occurs nowhere else in the Kamilaroi materials, it is preceded by *; spelling of these words is particularly doubtful.

5 Abbreviations used in the glosses are: ablat - ablative case; cont - continuous; dat - dative case; dl - dual; erg - ergative case; fut - future tense; habit - habitual; imper -- imperative mood; loc locative case; nfut - non-future tense; pres - present tense; prog - progessive; purp - purposive; rel - relative clause; sense - sensory evidence; $\mathrm{tr} \mathrm{vb}$ - transitive verbalizer. 


\section{'dinewan 'pular 'puralka}

1. 'dinewan

'pular
with
pulaarr
two

puralka
brolga (female)
purralka
brolga

jana gilani

emu (female)

two

brolga

goes gathering

wu $\check{u k a: k o .}$

'wuðuka

wuthukaa-ku.

emu yana-ngila-nhi

root type-dat

'The emu went with the brolga to gather wuthukaa roots.'

2. 'neiru na

'mo: ni'lani

They went over

digging up it

ngaarringa

mawu-ngila-nhi

over there

dig-cont-nfut

'They spent their time digging.'

3. bularu

both

'purula:ko

'kaingil

pulaarr-u

many

children (possessed)

two-dat

purrulaa-ku

kaaynkil

'Both of them had many children.'

4. 'ma:lu

wina nani

one of them (i.e. the emu

maal-u

one-erg

thought of it 〈the plan to trick the brolga >

winanga-nhi

think-nfut

jale

'nurago

jana wondai

as

towards camp

went

yalu ngurra-ku

again

camp-dat

yana-waa-ndaay

go-prog-rel

'One of them thought of a trick (to play on the other) as she walked with him to camp.'

5. jalu: namil a'rindai "in the morning"

yalu ngami-ingari-ndaay

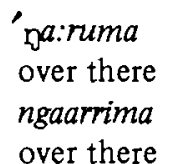

'puralka

'nari

the brolga

was

again see-morning-rel

purralka

ngarri-y

brolga

sit-nfut

'Next morning she saw the brolga over the way.'

$\begin{array}{ll}\text { 6. 'puralka } & \text { kokoe } \\ \text { brolga } & \text { asked: } \\ \text { purralka } & \text { kaka-y } \\ \text { brolga } & \text { call out-nfut }\end{array}$

'The brolga asked.' 
7. "tala:ra ginu

'kaingal"

where your

children

thalaa-? nginu

kaaynkil

where you genitive

child

'Where are your children.'

Answered the emu:-

8. "a! 'bum:ai"

ah! I killed them

aa puma-ay

ah kill-nfut

'Ah I killed them.'

9. "'minjako?"

what for

minya-ku

what-dat

'Why?'

10. “'kamila 'nuðar'ulun'dai

unable to feed them

kamila *nguthaRu-laa-ndaay

cannot feed-prog-rel

'I was unable to feed them all.'

11. "'naraka! 'minjako?

poor things! what for?

ngarrakaa minya-ku

poor thing what-dat

'Poor things - why?'

12. "a! 'kamila wuðilandai

'toarminja

cannot feed them their food

aa kamila wuu-thila-ndaay thuwarr minya

ah cannot give-?-rel food something

'I cannot give them food enough.'

$\begin{array}{llll}\text { 13. ' } 1 \text { inda 'bula } & \text { 'kuli:r kola } & \text { tealumai } & \text { 'boma'la:bilika } \\ \text { you yourself } & \text { husband } & \text { ask } & \text { whether you can }\end{array}$

nginta-pulaa kuliir kuwaa-la thayaluma-y puma-laa-pilika

you-self spouse speak-imper ask-fut kill-prog-?

'You ask your husband whether you can kill yours also.' 
EMU AND BROLGA

14. 'kaminda burula:

you won't the whole crowd

kamil-nta purrulaa *nguthaRu-lta-yku

not-you many feed-prog-purp

'Then you won't have to feed so many.'

15. "naleike Đundi tuar: kuraldana"

from you and me food eat too much

ngali-kii-ngunti thuwarr *kuRa-lta-nha

we dl-oblique-ablat food take-prog-pres

'They take too much food from us.'

16. "“ki:r! yes

'paija

'koei

kiirr

I

will tell

kuli:r

nai"

husband mine

yes

ngaya

kuwaa-y

kuliirr

ngay

spouse

I genitive

'Yes I will tell my husband about it.'

17. "ja:ma pali bomali

will we kill

yaama ngali puma-li

question we kill-fut

'kainkal gulbiri."

children some

kaaynkil kulpirr

child some

'Husband - will we kill some of our children?'

18. maneir 'Daleiki

why are they

? ngali-kii-ngunti

we dl-oblique-ablat

$\begin{array}{ll}\text { 'jundi } & \text { 'kuraldana } \\ \text { from us } & \text { eating } \\ & \text { *kuRa-lta-nha } \\ & \text { take-prog-pres }\end{array}$

'minjamin'japul everything minyaminyapul everything

'Why are they eating all our food?'

19.

$\begin{array}{lllll}\text { ga } & \text { ki:r! } & \text { 'bumali } & \text { 'gaingal } & \text { 'puralgalgar." } \\ \text { ah! } & \text { yes! } & \text { kill } & \text { children } & \text { the greater part } \\ \text { ngaa } & \text { kiirr } & \text { puma-li } & \text { kaaynkil } & \text { purrul-kalkaa } \\ \text { ah } & \text { yes } & \text { kill-fut } & \text { child } & \text { big-plural }\end{array}$

'Oh yes. Kill most of the children.'

(The next day the female brolga meets the woman emu again while food gathering:- )

20. "ja:ma "kara nal"

"how is it now"

yaama-karra-ngal

question-sense-?

['How's things?'] 
21. 'na:, 'ki:r, boma'labekeir."

ah yes I killed them

ngaa kiirr puma-laa-?

ah yes kill-prog-?

['Ah yes I killed them.']

22. najil bula:r ijil ka: 'wa:na."

now two only I fetch along

nhayil pulaarr yiyal kaa-waa-nha

now two only bring-prog-pres

['Now I have only two to bring along.']

23. "a! 'keiru:mai."

ah you did it

aa giirru-ma-ay

ah truely-tr vb-nfut

['Ah you did it.']

24. “'maruwa' วai 'jene jene je'le

out here (like this) they walk

marra-bathaay yana-yana-yla-y

there-like go-go-prog-fut

['There they are walking along.']

25. 'maraa'ðai

out here

marra-bathaay

there-like

'turali
all
*thuRa-li
?-fut

'kaingal

my youngsters

kaaynkil-kalgaa

child-plural

['There the children come.']

26. jaleigol! maruwa'ðai naija 'puru'la

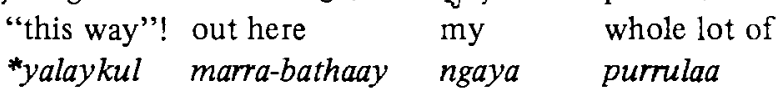

this way there-like I many

'kaingal 'kar ke'reigul

children I am leading

kaaynkil kaa-?

child bring-?

['This way over there I am bringing my many children.'] 


\section{EMU AND BROLGA}

27. ' "away" went the brolga

*ngima-palanga yana-nhi purralka away-? go-nfut brolga

['The brolga went away.']

28. 'peir ta'la pari

long distance away remained "sat down" a long time

ngiirr thalaa ngarri-yngayi-la-nhi

there somewhere sit-habit-prog-past

['She stayed away for some time.']

(The brolga is very sad at being tricked into killing her children. She remains away "twelve months" and returns. She sees the emu walking about gathering food as before.)

$\begin{array}{lllll}\text { 29. “ } \mathrm{a} a ! & t a{ }^{\prime} t a & \text { wanda } & \text { pareia } & \text { weilani. } \\ \mathrm{ah} & \text { where } & \text { far away } & \text { you remained } & \text { a long time }\end{array}$

ngaa thalaa wantha ngarri-yngayi-la-nhi

ah somewhere distant sit-habit-prog-past

['Oh you stayed away a long time.']

30. of piliminja jeneweinje kamil wina na naileigu

from here went off away so as not be thinking

${ }^{*}$ ngiliminya yana-waa-nhi kamil winanga-yngayi-la-yku

from here go-prog-past not think-habit-prog-purp

['I went from here so as not to be thinking about them.']

〈The brolga woman is feeding with her mouth, her arms are hidden behind her back.

She is acting a part to trick the emu. $)$

31. "pominja

why are you

taldanei

ngaa minya

eating (as you are)

ah what

tha-lta-nha

eat-prog-pres

['Why are you eating so?']

32. a! 'borei!

a werinja bo jon ginji a

oh sister

aa *puuRi

it happened arms of me

ah elder sister

?

pungun kinyi

arm be-press

'karal weinji."
we cut off away
karra-layla-nyi
cut-before-past

['Ah sister I cut off my arms.'] 
33. "minjako?"

what for

minya-ku

what-dat

['What for?']

34. "jalai waðai maru taldaigo"

this way just like this I feed

yilaay-pathaay maru tha-lta-yku

thus-like good eat-prog-purp

['It is good to eat like this.']

35. "bonon dali ba:ga"

arms feed not

pungun tha-li ?

arm eat-fut

['I'll eat without using my arms.']

36. "na jei!"

"I see"

ngaayay

all right

['All right.']

37. ' gindu baðai

you

bo jon gara 'nilia

ngintu-pathaay pungun karra-ngili-ya

you-like arm cut-cont-imper

['You cut off your arms like this.']

38. 'minjako 'wara"

what for do that

minya-ku ?

what-dat

['What for?']

39. o! maro waðai taldainda jele 'neia

oh good like this eating will be like myself

maru-pathaay tha-lta-ntaay yila ngaya

good-like eat-prog-rel like I

['Oh it would be good to eat like me.'] 


\section{EMU AND BROLGA}

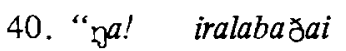

jana wuindai

ah! when like this

I go back

ngaa yilaala-pathaay yana-wuwi-ntaay

ah this-like go-back-rel

['Ah I'1l go back like this.']

41. 'ki:r! daijalumi koli:r nai

yes I will ask husband mine

kiirr thayaluma-y kuliirr ngay

yes ask-fut spouse I genitive

'weira ko:li

if say

? kuwaa-li

kei 'riar

"he might"

kiirru-?

truly

['I'll ask my husband if he will say I can.']

42. "ทa keir. kara ฤeileigo tara woinindai

oh yes cutting them off

ngaa kiirr karra-ngili-yku ?-wuwi-ngintaay

ah yes cut-cont-purp ?-back-rel

jera:la

bye \& bye

yilaalu

later

'Oh, yes we will cut them off tonight.'

43. kulibarga jereganda

three suns

kulipaa-ka *yaRakan-ta

three-loc sun-loc

'Three days later.'

44. "ja:ma 'gara nai" how cutting yaama-karra-ngay question-sense-

['How's things?']

45. 'ki:r bo jon 'karanilinji

yes arms we have cut off

kiirr pungun karra-ngili-nyi

yes arm cut-cont-nfut

['Yes I cut off my arms.'] 


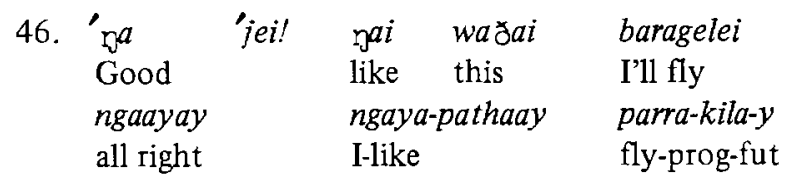

['All right I'1l fly like this.']

47. 'dawunda jenelei

on the ground you will go

thawun-ta yana-la-y

ground-loc go-prog-fut

['You will go on the ground.']

$\begin{array}{lll}\text { 48. 'raija bala 'parai po Đon baijai } \\ \text { I myself } & \text { flying arms will fly } \\ \text { ngaya-pala } & \text { parra-y } & \text { pungun-paraay } \\ \text { I-only } & \text { fly-fut arm-having }\end{array}$

['Only I will fly with my wings.']

\section{NOTES ON THE TEXT}

Tindale (1938:137) has the following notes from the storytellers:

formerly both the emu and brolga had large families; the old emu took two with her and hid the others in a patch of bush. The emu tricked the brolga (and) that is why the brolga only lays two eggs today.

The brolga when he has his wings folded does not show them very much. After she had had her revenge, she danced and jigged with happiness - the brolgas still do this."

A story almost identical to this Kamilaroi myth is presented in Parker (1978:17-20) as 'Dinewan the Emu and Goomblegubbon and Bustard'. A Yuwaalaraay version of the text is given on pp.187-9. Williams (1980:131) presents the story of emu and brolga as told to her in Yuwaalaraay by Arthur Dodd in 1978; it is a very brief text which corresponds to the first half of the one told by Harry Doolan. ${ }^{6}$

6 Robinson (1966:196-7) contains a text in English entitled Dinnawun and burralga, related to him by Maria Boney, 'Yoalarai' (i.e. Yuwaalaraay) tribe. 
A mythological story similar to this is also known to descendants of the Wiradjuri who formerly occupied the country to the south of the Kamilaroi. Len ('Bushi') Kirby of Murrin Bridge has published a story entitled 'Emu and Native Companion' (Kirby 1982) which describes the trick played by brolga on emu, though no mention is made of the emu's hiding her children. Tamsin Donaldson (personal communication) recorded a text in English entitled 'The native companion and the emu' from Isobel Edwards of Darlington Point on 17th July 1980. Mrs Edward's text is almost identical to the Kamilaroi story except that the respective tricks of brolga and emu are presented in the opposite order to that presented in the text above.

The themes of these New South Wales texts recur, with some variations, across the continent. Reed (1978:114-7) presents an Emu and Brolga story from the Murray River region and Massola (1971:43) has one from south-eastern Australia (no more detailed localisation is given). In Massola's version the Emu burns (rather than cuts) her wings off and then tricks Brolga into killing (and eating) her children. The order of events is thus reversed from the Kamilaroi text, but the same as in the story collected by Donaldson. Tindale is preparing for publication a Tanganekald (South East of South Australia) legend similar to the Kamilaroi text. In one version of the Tanganekald story there is a contest between the two birds, involving an attempt at revenge by the brolga who causes a marine flood over a large area of land favoured by the emu. In South and Western Australia we find texts dealing with emu and bustard (wild turkey), rather than brolga. Schebeck (personal communication) recorded an Adnyamathanha (Flinders Ranges) myth in which emu and bustard appear as sisters (see also Mountford 1976). Events similar to those found in the Kamilaroi text occur. Austin has also recorded a traditional text of the Jiwarli (Gascoyne region, Western Australia) involving emu and bustard (see Butler and Austin 1985). In this story the two birds test who can fiy best and who can run best. Emu's legs stick out when he ${ }^{7}$ flies but he is able to run fast, so he is advised by bustard to cut off his wings. There is no trickery involved in the Jiwarli text and no mention of emu tricking the other bird into killing his children. ${ }^{8}$ A Cape York peninsula version of the story in the Yadhaykenu dialect of Uradhi told by Willie Somerset is presented by Crowley (1983:391-7). Again, emu and bustard are involved and similarities to the Kamilaroi text are striking, for example, the first line (in translation) reads '[There were] two of them going for scrub yams.' The bustard tricks the emu into burning her wings off and in return the emu tricks bustard into killing her children (cf. the reversal of themes in the texts recorded by Donaldson from a person of Wiradjuri descent and by Massola). Fire is again mentioned in a story entitled 'Nurrun the emu and manor the plain turkey' presented in English by Bozic (1972:57-9). Interestingly, the emu and bustard are described as a married couple; unfortunately there is no location given for the text but it is possible that 'Nurrun' is intended to represent Wiradjuri ngurruny 'emu'.

Evidently, the Kamilaroi text is one version of a widespread mythological complex involving several motifs:

7 There is no indication in Jiwarli of the sex of the protagonists. The masculine English pronoun is intended in its unmarked sense. A running competition story is also found in Merritt (1983:14-15) where a myth involving emu and curlew (not brolga or bustard) is outlined. Merritt is of Wiradjuri descent.

8 Donaldson has brought to our attention Pritchard (1929[1975]) which contains a partial emu and bustard text in pidgin English from the Ngarla area (northern Pilbara). 
(a) emu and brolga (or bustard)

(b) competition (and in some places trickery)

(c) mutilation of emu by cutting or by fire

(d) brolga (or bustard) murdering her children.

These themes and texts containing them, are as widely distributed across the Australian continent, if not more so, as the well-known eaglehawk and crow myths (see Map 2). ${ }^{9}$

The following are specific comments (mainly linguistic) on the Kamilaroi text:

1. line 1 - pulaarr is the usual word for 'two'. Its occurrence between the two nouns here seems to indicate a use as a conjunction. wuthukaa is a type of edible root which grows in the black soil plains. Williams (1980:191) translates it as 'tar vine'.

2. line 3 - the occurrence of dative $-k u$ on purrulaa does not appear to be correct because the sense is 'of the two [there were] many children'.

3. line 8 - preceding lines $8,10,12$ in the margin Tindale wrote 'emu'. Preceding lines 9 , 11,15 in the margin is 'brolga'.

4. line 10 - the root of the verb in this sentence is not to be found in other Kamilaroi materials. The use of the relative clause form here suggests it is offered as a reason 'because I cannot (continue to) feed them' (see also lines $12,39,40$ ).

5. line 12 - the element -thila- cannot be analysed here. The verb wuu- is in the $r r$ class and derived forms normally involve this consonant, rather than th. It is possible that a continuous form -rrila- was intended.

6. line 14 - this example shows a bound subject marker affixed to the negative particle. The medial 1 is morphophonemically deleted.

7. line 15 - the vowel length of the oblique stem formant is not certain, but compare Ngiyampaa -kiiN- (Donaldson (1980:123)).

8. line 17 - in the margin Tindale wrote 'brolga to husband'.

9. line 18 - the word maneir is unclear; normally 'why?' is based upon minya 'what'.

10. line 19 - in the margin Tindale wrote 'old man brolga'.

11. line 20 - in the margin Tindale wrote 'emu'. The analysis of this sentence is somewhat tentative but it is likely that it is a greeting consisting of yaama, the question introducer, plus -karra, a clitic indicating a statement based upon sensory evidence. A parallel construction is found in Ngiyampaa (see Donaldson, 1986:139).). Identification of the final syllable is unclear. There it is written as -ngal and in line 44 as -ngay. Austin recorded a Kamilaraay greeting yaamangay, which seems also to contain -ngay.

12. line 21 - in this margin Tindale wrote 'brolga'. The analysis of bakeir is unclear. It may contain kiirr 'truly'.

13. line 23 - in the margin Tindale wrote 'emu'.

14. line 25 - the verb in this sentence is not found in other Kamilaroi materials.

15. line 27 - a suffix -palanga is also found in Williams' text (1980:131). She was unable to gloss it.

16. line 29 - in the margin preceding lines $29,31,33,36,38,40$ and 45 is 'emu'. Preceding lines $30,32,34,37,39,44$ and 46 is 'brolga'.

17. line 37 - under baðai Tindale has 'waðai, like this, 'better go, had better'.

18. line 42 - in the margin Tindale wrote 'emu husband'.

19. line 43 - the usual Kamilaroi term for 'sun' is yaraay.

9 See Maddock 1978 for a comparison of myths of this type (which he calls 'Southern') and Dalabon texts featuring the emu. 


\section{EMU AND BROLGA}

\section{BIBLIOGRAPHY}

Austin, P., C.I. Williams \& S.A. Wurm. 'The linguistic situation in north central New South Wales', in Rigsby B. and P. Sutton eds. Contributions to Australian linguistics. Canberra: Pacific Linguistics, A-59, 1980:167-80.

Austin, P. and S.A. Wurm. Materials in Kamilaraay, northern New South Wales. Canberra, Pacific Linguistics, (in preparation).

Bozic, S. Aboriginal myths. Melbourne, 1972.

Butler, J. \& P. Austin. Jiwarli texts. La Trobe University, computer printout, 1985.

Crowley, T. 'Uradhi', in Dixon R.M.W. and B.J. Blake eds. Handbook of Australian languages. Volume 3, Canberra, 1983: 307-428.

Dixon, R.M.W. Searching for Aboriginal languages: memoirs of a fieldworker. University of Queensland, 1984.

Donaidson, T. Ngiyambaa: the language of the Wangaaybuwan. Cambridge, 1980.

'From Speaking Ngiyampaa to speaking English', Aboriginal History, this volume, 1986:126-147.

Greenway, Rev. C.C. 'Scripture narratives in Kamilaroi', Science of Man, 1911 13(3):66, 13(4):86, $13(5): 106,13(6): 125-6$.

Kirby, L. 'Emu and Native Companion', Full flight. (Central Western Arts Project Newsletter) 6, 1982:7.

Maddock, K. 'The emu anomaly', in Hiatt, L.R. ed. Australian Aboriginal mythology. Canberra, 1978: 102-122.

Massola, A. The Aborigines of South Eastern Australia as they were. Melbourne, 1971.

Mathews, R.H. 'Language of the Kamilaroi and other Aboriginal tribes of New South Wales', Journal of the Royal Anthropological Institute, 33, 1903:259-83.

Merritt, R.J. The Cake Man. Sydney, 1973. (Revised ed.).

Mountford, C.P. The Wild Turkey and the Emu, in Ainslie Roberts with text by Charles P. Mountford. Before Time Began. Australian Aboriginal myths in paintings. Melbourne, Sydney, Brisbane, Adelaide, Perth, 1976:49-51.

Parker, C.S. [K. Langloh Parker] Australian Legendary Tales: Folklore of the Noongahburras as told to the Piccaninnies. Sydney, 1896.

Australian Legendary Tales. Sydney, 1978. [Reprint of Parker 1896].

Pritchard, K.S. Coonardoo. Sydney, 1929[1975].

Reed, A.W. Aboriginal myths: tales of the Dreamtime. Sydney, 1978.

Ridley, Rev. W. Gurre Kamilaroi or Kamilaroi sayings. Sydney, 1856.

Kamilaroi and other Australian languages. Sydney, 1875.

Robinson, R. Aboriginal myths and legends. Melbourne, 1966.

Tindale, N.B. Journal of the Harvard-Adelaide University Anthropological Expedition. MS, 1938. Aboriginal tribes of Australia. Canberra, 1974.

'Some ecological bases for Australian tribal boundaries', in Peterson, N. ed. Tribes and boundaries in Australia. Canberra, 1976:12-29.

Williams, C.J. A grammar of Yuwaalaraay. Canberra: Pacific Linguistics, B-74, 1980.

Wurm, S.A. Kamilaroi fieldnotes. MS, 1955. 